\title{
KOORDINÁCIA ÚROVNE OCHRANY PRÁV V EURÓPE V KONTEXTE PRISTÚPENIA EURÓPSKEJ ÚNIE K DOHOVORU O OCHRANE LUDSKÝCH PRÁV A ZÁKLADNÝCH SLOBÔD
}

\author{
COORDINATION OF RIGHTS PROTECTION LEVEL IN \\ EUROPE IN THE CONTEXT OF THE ACCESSION OF THE \\ EUROPEAN UNION TO THE CONVENTION ON THE \\ PROTECTION OF HUMAN RIGHTS AND FUNDAMENTAL \\ FREEDOMS
}

\author{
Jana Vrabl'ová \\ Univerzita Pavla Jozefa Šafárika v Košiciach, Právnická fakulta
}

https://doi.org/10.33542/SIC2019-2-10

\begin{abstract}
ABSTRAKT
Tento príspevok analyzuje článok 53 Dohovoru o ochrane l'udských práv a základných slobôd a článok 53 Charty základných práv Európskej únie osobitne, vich vzájomnom vztahu a cez tvrdenie Súdneho dvora EÚ vo svojom Stanovisku 2/13, že dohoda o pristúpení môže ohrozit' charakteristické znaky a autonómiu práva Únie, pretože nezaručuje koordináciu týchto dvoch článkov. Ústrednou čast’ou článku je postoj Súdneho dvora, že ani po pristúpení k Dohovoru nebude vo veciach, v ktorých pôsobí únijné právo, tolerovat úroveň ochrany práv garantovaných Chartou v rozpore s rozsudkom Melloni. Autorka sa cez definovanie úrovne ochrany práv podl'a Dohovoru a podl'a Charty a analýzou príslušnej judikatúry, zamýšla nad tým, prečo je koordinácia článkov 53 z pohl’adu Únie nevyhnutná. Záver príspevku je venovaný pozorovaniu, akým smerom sa v období po stanovisku 2/13 uberá judikatúra ohl'adom štandardu ochrany práv.
\end{abstract}

\begin{abstract}
This article analyzes Article 53 of the Convention for the Protection of Human Rights and Fundamental Freedoms and Article 53 of the Charter of Fundamental Rights of the European Union in particular, in their mutual relationship and the assertion by the Court of Justice of the EU in its Opinion 2/13 that the Accession Agreement may jeopardize the characteristics and autonomy Union law as it does not guarantee the coordination of these two articles. The central part of the article is the position of the Court that, even after accession to the Convention, it will not tolerate the level of protection of the rights guaranteed by the Charter, contrary to the Melloni judgment, in matters governed by the EU law. The author, through the definition of the level of protection of rights under the Convention and according to the Charter and the analysis of relevant case-law, is considering why the coordination of Articles 53 from the point of view of the Union is necessary. The conclusion of the paper is to look at the way in which the case-law regarding the standard of protection of rights is taken in the period after opinion 2/13.
\end{abstract}




\section{I. ÚVOD}

Zmluva o Európskej únii v lisabonskom znení dala Európskej únii (d’alej len „EÚ" alebo „Únia") právnu subjektivitu a výslovne ju zaviazala pristúpit’ k Dohovoru Rady Európy o ochrane l’udských práv a základných slobôd (d’alej len „Dohovor“). Členské štáty EÚ a Rady Európy sa dohodli na texte Dohody o pristúpení EÚ k Dohovoru z 5. apríla 2013 (d’alej len „,dohoda").Následne ju v zmysle čl. 218 ods. 11 Zmluvy o fungovaní EÚ (d’alej len „ZFEÚ") posudzoval Súdny dvor Európskej únie v Luxemburgu (d’alej len „Súdny dvor"). Vo svojom stanovisku 2/13 z decembra 2014 Súdny dvor vyhlásil, že návrh dohody je nezlučitel'ný so zmluvami a nastolili sa právne i politicky zložité otázky. Aj napriek tomu, že dohoda nerieši prípadnú disharmóniu súbežného uplatňovania článku 53 Dohovoru a článku 53 Charty po pristúpení, Súdny dvor vyjadril, že bez koordinácie týchto článkov v dohode, budú autonómia a charakteristické znaky práva Únie ohrozené. Súdny dvor nepožaduje len koordináciu, ale aj obmedzenie pôsobenia článku 53 Dohovoru tak, aby úroveň ochrany práv garantovaných Chartou bola $\mathrm{v}$ súlade $\mathrm{s}$ jej výkladom $\mathrm{v}$ rozsudku Melloni. V článku porovnávame úroveň ochrany práv garantovaných Dohovorom a Chartou podl'a znenia článkov 53 a podl'a sily, ktorú týmto článkom dávajú rozsudky Súdneho dvora a Európskeho súdu pre l'udské práva v Štrasburgu (d’alej len „ESLP") a uvažujeme o možných dôvodoch, pre ktoré Súdny dvor považuje obmedzenie článku 53 Dohovoru v dohode za nevyhnutné.

\section{II. ÚROVEŇ OCHRANY PRÁV PODLA ČLÁNKOV 53 1. Úroveň ochrany práv podl'a Dohovoru}

Článok 53 Dohovoru zakotvuje, že ,nič v tomto dohovore sa nebude vykladat' tak, aby obmedzovalo alebo zasahovalo do výkonu l’udských práv a základných slobôd, ktoré môžu byt' uznané zákonmi ktorejkol'vek Vysokej zmluvnej strany alebo akýmkol’vek iným dohovorom, ktorého je táto zmluvnou stranou. " ${ }^{1}$ Dohovor na základe toho vytvára len akýsi minimálny štandard ochrany l'udských práv, ku ktorému sa členské štáty pristúpením k Dohovoru zaviazali. To im však priamo nezakazuje nastavit' ústavné štandardy ochrany l'udských práv vyššie, ako ich určuje samotný Dohovor, a to či už samostatne vo vlastnom ústavnom poriadku, alebo aj na základe pristúpenia k d’alším medzinárodným zmluvám o ochrane l'udských práv. „Vzhl'adom na uvedené sa ústavné súdy členských štátov Rady Európy nachádzajú v pomerne komplikovanej pozícii, v ktorej musia vykladat' vlastné ústavné štandardy ochrany základných práv, zväčša vo svetle svojich d'alších medzinárodných záväzkov. Pri tom musia zohl'adňovat' a predvídat' progresívne sa rozvíjajúcu judikatúru ESLP, ktorá interpretuje Dohovor. Inak riskujú možné porušenie až následne deklarovaného práva, ktoré podl'a ESLPP vyplýva z Dohovoru. Pri týchto procesoch sú oprávnené poskytovat’ ochranu práv v tzv. zvýšenom štandarde, no súčasne pri interpretácii práv, ktoré môžu byt' vo vzájomne konfliktnej pozícii, nesmú zasiahnut' minimálny štandard iných práv vyplývajúcich z Dohovoru, pretože judikatúra ESLP je ochotná pripustit' len taký zvýšený štandard ochrany, ktorý neporuší efektívnu ochranu d’alších práv uvedených $\mathrm{v}$ Dohovore. ${ }^{2} Z$ toho vyplýva, že napriek explicitnému zneniu čl. 53 si Dohovor prednostnú aplikáciu implicitne nárokuje." ${ }^{3}$

\footnotetext{
Článok 53 Dohovoru.

Napr. Rozhodnutie Európskeho súdu pre l'udské práva zo dňa 7. februára 2012 vo veci Axel Springer AG v. Nemecko, St'ažnost' č. 39954/08.

BARANÍK, K.: Interakcia medzinárodného, supranacionálneho a ústavného práva pri ochrane l'udských práv v SR. In: Justičná revue, 69, 2017, č. 10, s. 1117 - 1137.
} 


\section{2. Úroveň ochrany práv podl'a Charty}

Od nadobudnutia účinnosti Charty v roku 2009 je klúčcovým ustanovením, ktorým sa riadi vzt’ah medzi týmto dokumentom a Dohovorom, doložka o homogénnosti v článku 52 ods. 3 a článok 53 zaručuje minimálnu úroveň ochrany rovnocennú s tou, ktorú garantuje Dohovor. Článok 53 Charty stanovuje, že ,žiadne ustanovenie tejto charty sa nesmie vykladat' tak, že obmedzuje alebo poškodzuje l’udské práva a základné slobody uznané v rámci príslušného rozsahu ich pôsobnosti, právom Únie, medzinárodným právom a medzinárodnými zmluvami, ktorých zmluvnou stranou je Únia alebo všetky členské štáty, a najmä Európskym dohovorom o ochrane l'udských práv a základných slobôd, ako aj ústavami členských štátov." ${ }^{4}$ Pôsobnost' Charty je zúžená v čl. 51, v ktorom sa ustanovuje rozsah jej pôsobnosti. Na základe toho sa tak práva v Charte vzt’ahujú na inštitúcie EÚ a tiež na členské štáty výlučne vtedy, ak vykonávajú právo Únie. ${ }^{5}$

Súčasne je v čl. 53 ustanovené, podobne ako to bolo pri Dohovore, že Charta nebude na ujmu právam v tzv. vyššom štandarde národných ústavných práv. ${ }^{6}$ Rovnako však ako pri Dohovore, je „zužujúce" gramatické znenie týchto ustanovení Charty v protiklade $\mathrm{s}$ realitou vytváranou rozhodovacou činnost'ou Súdneho dvora EÚ. Možnost' členských štátov odvolávat' sa prostredníctvom čl. 53 Charty na vyšší štandard národných ústavných práv Súdny dvor vylúčil v prípadoch, ak by došlo $\mathrm{k}$ porušeniu efektivity práva EÚ. Uvedené sa deje v podstate i napriek tomu, že Charta takéto explicitné odmietnutie vyššieho štandardu ochrany poskytovaného členskými štátmi neobsahuje. Súdny dvor pri tom vel’mi zásadným spôsobom uviedol, že ,,.. vnútroštátne orgány môžu uplatnit' vnútroštátne štandardy ochrany základných práv, pokial' toto uplatnenie neohrozí úroveň ochrany vyplývajúcej z Charty, ako ju vykladá Súdny dvor, ani prednost', jednotnost' a účinnost' práva Únie." ${ }^{7}$

\section{Doktrína judikatúry Súdneho dvora v otázke štandardu ochrany práv}

„V známom prípade Melloni Súdny dvor nevzal do úvahy výklad čl. 24 ods. 2 Ústavy Španielskeho král'ovstva, podl'a ktorého sa osoba odsúdená v neprítomnosti vydá len vtedy, ak sa jej v dožadujúcom štáte zaručí nové konanie vo veci samej, hoci by sa to javilo ako poskytnutie vyššej úrovne ochrany základných práv, než je úroveň poskytovaná Chartou. “8 ${ }^{\text {8 }}$ Súdny dvor vylúčil doplńnanie požiadaviek na vydanie na základe vnútroštátnych úprav alebo výkladových pravidiel vnútroštátnej judikatúry, ktoré by ohrozilo úroveň ochrany vyplývajúcu z Charty a tiež princíp prednosti, jednotnej aplikácie a plnú účinnost' práva Únie, a to aj v situácii, ak by vnútroštátna úprava viedla $\mathrm{k}$ vyššiemu štandardu ochrany základných práv osoby, ktorá bola odsúdená v neprítomnosti. Členské štáty si dnes na základe čl. 53 Charty, v spojitosti s vlastnými ústavnými poriadkami, nemôžu nárokovat' výnimku z uplatňovania práva EÚ, ak by to mohlo narušit' efektívne pôsobenie práva EÚ. Súdny dvor tým deklaroval, že ohrozenie prednosti, jednotnosti a účinnosti práva Únie nebude $\mathrm{v}$ národných koncepciách ochrany l'udských práv tolerovat'.

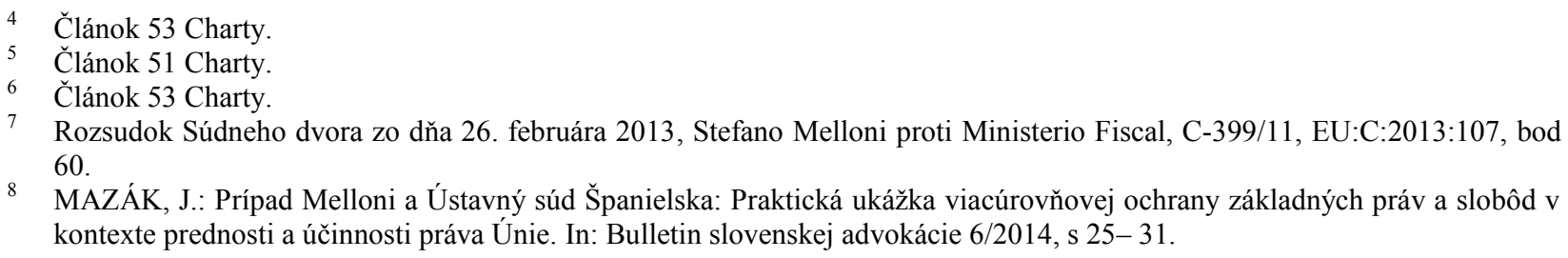

8 MAZÁK, J.: Prípad Melloni a Ústavný súd Španielska: Praktická ukážka viacúrovňovej ochrany základných práv a slobôd v kontexte prednosti a účinnosti práva Únie. In: Bulletin slovenskej advokácie 6/2014, s 25-31. 
V nadväznosti na evidentnú tendenciu oboch súdov chránit' prednostné pôsobenie a jednotnú aplikáciu týchto l'udsko-právnych dokumentov vo vzt’ahu k vnútroštátnym právnym poriadkom, nie je možné opomenút' to, aký je v predmetnej problematike vzájomný vzt’ah Dohovoru a Charty. Ako už bolo vyššie spomenuté, Charta je v čl. 52 ods. 3 vel'mi precízna v definovaní rozsahu a výkladu práv a zásad $\mathrm{v}$ nej garantovaných: ,,v rozsahu, v akom táto charta obsahuje práva, ktoré zodpovedajú právam zaručeným v Európskom dohovore o ochrane l'udských práv a základných slobôd, zmysel a rozsah týchto práv je rovnaký ako zmysel a rozsah práv ustanovených v uvedenom dohovore. Toto ustanovenie nebráni tomu, aby právo Únie priznávalo širší rozsah ochrany týchto práv." ${ }^{9}$ Opät' je ale nevyhnutné sledovat' aj judikatúru Súdneho dvora. Súdny dvor roku 2010 uviedol, že, ak práva Charty sú rovnaké ako práva uvedené v Dohovore, Súdny dvor by sa mal riadit' jasnou a konzistentnou judikatúrou ESLP ${ }^{10}$. Neskôr v roku 2014 už ale Súdny dvor stanovil, vychádzajúc z čl. 52 ods. 3 Charty, že judikatúra ESLP musí byt' zohl'adnená na účely výkladu jej ustanovenia. ${ }^{11}$ Smerovanie Súdneho dvora je dost' zrejme, nakol'ko sa $\mathrm{v}$ otázke výkladu práv Charty uberá od riadenia sa judikatúrou ESL'P $\mathrm{k}$ jej zohl'adňovaniu. A Charta núka svoje prvenstvo v úrovni ochrany ňou garantovaných práv, ked' sa nebráni tomu, aby právo Únie chránilo práva, ktorých zmysel a rozsah je v Charte a Dohovore rovnaký, v širšom rozsahu.

\section{VYJADRENIE SÚDNEHO DVORA O KOORDINÁCII ČLÁNKOV 53}

Súdny dvor vo svojom stanovisku 2/13 z 18. decembra 2014 konštatoval, že zamýšlaná dohoda môže ohrozit' charakteristické znaky a autonómiu práva Únie ${ }^{12}$, pretože nezaručuje koordináciu medzi článkom 53 Dohovoru a článkom 53 Charty. V bode 188 tohoto stanoviska pripomenul, že Súdny dvor už skôr vyložil článok 53 Charty v zmysle doktríny Melloni, čim jednoznačne potvrdil, že bude aj v otázke pristúpenia presadzovat' úroveň ochrany stanovenú v Charte a chránit' prednost', jednotnost' a účinnost' práva Únie. Súdny dvor si pred pristúpením vyžiadal nie len koordináciu článkov 53 ale vyslovil aj požiadavku na obmedzenie pôsobenia Dohovoru. V rozsahu, v akom článok 53 Dohovoru v podstate vyhradzuje možnost' Zmluvných strán upravit' vyššie štandardy ochrany základných práv, než aké zaručuje Dohovor, treba podl'a Súdneho dvora zabezpečit' koordináciu medzi týmto ustanovením a článkom 53 Charty, tak, ako ho vykladá Súdny dvor, aby možnost’ poskytnutá článkom 53 Dohovoru členským štátom zostala obmedzená - pokial' ide o práva uznané Chartou a zodpovedajúce právam zaručeným uvedeným Dohovorom - v rozsahu potrebnom na to, aby nebola ohrozená úroveň ochrany stanovená Chartou ani prednost', jednotnost' a účinnost' práva Únie. ${ }^{13}$ Súdny dvor tak vyjadril obavu, že článok 53 Dohovoru by po pristúpení dokázal oživit’ štandard ochrany práv v rozpore s tým, čo uviedol v rozsudku Melloni.

\section{IV. ÚVAHY O NEVYHNUTNOSTI KOORDINÁCIE ČLÁNKOV 53 Z POHLADU EÚ}

9 Článok. 52 ods. 3 Charty.

10 Rozsudok Súdneho dvora zo dňa 5. októbra 2010, J. McB. proti L.E., vec C-400/10, EU:C:2010:582, bod 53.

11 Rozsudok Súdneho dvora zo dňa18. decembra 2014, Centre public d'actionsociale d'Ottignies-Louvain-la-Neuve proti Moussovi Abdidovi, vec C-562/13, EU:C:2014:2453, bod 47.

12 Pokial' ide o autonómiu právneho poriadku Únie, treba poznamenat', že zakladajúcimi zmluvami Európskej únie bol vytvorený nový právny poriadok sui generis, inými slovami autonómny právny poriadok. Pokial' ide o charakteristiky Únie ako viacúrovňového systému, za daných relevantných súvislostí patrí medzi ne predovšetkým to, že v rámci Únie sú právomoci a zodpovednost' na základe celej rady ustanovení primárneho a sekundárneho práva rozdelené medzi vnútroštátne orgány a orgány Únie.

13 Stanovisko Súdneho dvora z 18. decembra 2014, 2/13, EU:C:2014:2454, bod 189. 
Máme za to, že ak by Súdny dvor požadoval koordináciu článkov 53 iba s úmyslom chránit' úroveň ochrany stanovenú Chartou, musel by uznat', že úroveň ochrany je v článku 53 Charty už aj tak limitovaná právom Únie, medzinárodným právom a medzinárodnými zmluvami, ktorých zmluvnou stranou je Únia alebo všetky členské štáty, a najmä Dohovorom, ako aj ústavami členských štátov. A rovnako, ak teraz únijné právo nedovol'uje svojim členským štátom poskytovat' vyššiu úroveň ochrany práv garantovaných Chartou, ktorá by ohrozila prednost', jednotu a efektívnost' práva EÚ, tak nič na tom nezmení ani budúce pristúpenie EÚ $\mathrm{k}$ Dohovoru. ${ }^{14}$ Pri pokuse členského štátu EÚ o využitie článku 53 Dohovoru na účely zavedenia vyššieho štandardu ochrany práv, tento štandard by mohol byt' napokon jednoducho v zmysle Melloni doktríny Súdnym dvorom upravený do podoby, ako ju garantuje Charta. Zrejme tu ide o niečo viac.

Súdny dvor tvrdí, že bez nastavenia pravidiel súbehu týchto dvoch článkov, bude prednost', jednotnost' a účinnost' práva Únie ohrozená. V podstate ide o poistenie prednosti práva EÚ a toho, že ESLP nebude po pristúpení spochybňovat' túto pozíciu únijného práva s odkazom na článok 53 Dohovoru. Týmto spôsobom sa Súdny dvor snaží vyhnút prípadnému sankcionovaniu ESLP za to, že členskému štátu bráni uplatňovat' vyššiu úroveň ochrany práv než je tá garantovaná Chartou. Po pristúpení by sa totiž mohol aj voči Únii uplatnit' článok 33 Dohovoru, podla ktorého „každá Vysoká zmluvná strana môže predložit' súdu na preskúmanie každé porušenie ustanovení dohovoru a jeho protokolov, za ktoré podl'a jej názoru nesie zodpovednost' iná Vysoká zmluvná strana." 15

Podla Súdneho dvora by bolo najvhodnejšie, už v prístupovej dohode jasne definovat', že článok 53 Dohovoru-možnost' poskytnút' právam v ňom uznaným vyššiu úroveň národnej ochrany-bude členský štát Únie môct' uplatnit' len v súlade s článkom 53 Charty, presnejšie s jeho výkladom v rozsudku Melloni. Zrejme sa desí toho, že v opačnom prípade by došlo skôr či neskôr k nespokojnosti členských štátov Únie, ktoré by sa so svojou st’ažnost'ou voči Únii obrátili na ESLP. Obavy Súdneho dvora sú pravdepodobne na mieste vzhl’adom k tomu, že nie všetky ústavné súdy by pristúpili k podobnému „diktátu" Súdneho dvora tak pokorne, ako to urobil Španielsky ústavný súd v prípade Melloni. ${ }^{16}$ Zdá sa, že Súdny dvor si pred pristúpením uvedomil ešte čosi nepríjemnejšie, než je situácia, v ktorej členský štát Únie prizná v porovnaní s Chartou vyššiu úroveň ochrany. Lebo reálne, asi nie častý bude záujem Európskej komisie alebo iného členského štátu podávat' žalobu podl'a čl. 258, resp. 259 ZFEÚ voči tomuto štátu. Predmetom takejto žaloby by muselo byt' tvrdenie, že orgány členského štátu pristupovali $\mathrm{k}$ žiadatel'om o ochranu (nie len v oblasti azylového práva), či už z hl’adiska materiálnej ochrany alebo v procesnej rovine príliš vel'koryso a že v súlade s výkladom článku 53 Charty mali poskytnút' nižší štandard ochrany. Ale naopak, súbeh týchto dvoch článkov bez konkrétnejšej koordinácie $\mathrm{v}$ prístupovej dohode za súčasného presadzovania, že únijný štandard ochrany musí byt' v

14 JACQUÉ, J.: What next after Opinion 2/13 of the Court of Justice on the accession of the EU to the ECHR? [online], [cit. 8/05/2019]. Dostupné na internete: <file:///C:/Users/MOHI/Downloads/QA0416603ENN.en\%20(1).pdf>.

15 Článok 33 Dohovoru, toto ustanovenie treba chápat' v spojení s článkom 55 Dohovoru, podl’a ktorého zmluvné strany v zásade súhlasia, že spory vyplývajúce $\mathrm{z}$ výkladu alebo vykonávania Dohovoru nebudú predkladat' k inému spôsobu urovnania, než je stanovené v Dohovore. Pri vyjednávaní o zamýšlanom pristúpení Únie k Dohovoru tento problém vôbec nezostal bez povšimnutia. Na jeho vyriešenie bol do návrhu dohody vložený článok 5, podl'a ktorého konania pred Súdnym dvorom „nepredstavujú konanie na urovnanie sporov v zmysle článku 55 Dohovoru“. Vo vysvetl'ujúcej správe je toto ustanovenie návrhu dohody spresnené tak, že ,článok 55 Dohovoru nevylučuje použitie pravidla zakotveného v článku 344 ZFEÚ- predkladat' spory týkajúce sa práva Únie výlučne Súdnemu dvoru.

16 ŠpÚS nezaváhal a 20. februára 2014 zamietol ústavnú st’ažnost' S. Melloniho, zmeniac svoj doktrinálny prístup k otázke vydania osoby odsúdenej v neprítomnosti tak, že takéto vydanie, ak sa vykonáva na základe európskeho zatýkacieho rozkazu podl'a RR, nemôže podliehat' podmienke nového konania v dožadujúcom štáte. 
členských štátoch Únie aj po pristúpení k Dohovoru referenčným kritériom, je to, čo nenecháva Súdny dvor l'ahostajným.

Pri pohl'ade z iného uhla, ponechanie prístupovej dohody bez koordinácie článkov 53, by mohlo byt' skúškou lojality členských štátov voči Únii a opačne a rešpektu voči prednosti práva Únie. Máme predovšetkým na mysli situácie, v ktorých by st’ažnost' voči Únii alebo voči členskému štátu Únie podal na ESL'P jednotlivec a $\mathrm{v}$ súlade $\mathrm{s}$ pravidlami inštitútu spolužalovaného by štát alebo Únia podl'a okolností prípadu pristúpili do konania na stranu žalovaného, pre porušenie Dohovoru nepriznaním práva vo vyššom ústavnom štandarde, $\mathrm{z}$ dôvodu, aby nedošlo k ohrozeniu úrovne ochrany priznanej Chartou.

V prípade Melloni Súdny dvor potvrdil harmonizáciu predpokladov na vydanie osoby odsúdenej v neprítomnosti uvedených v článku 4a ods. 1 rámcového rozhodnutia 2002/584/SVV $\mathrm{v}$ platnom znení ${ }^{17}$ a konštatoval zlučitel'nost' citovaného článku s požiadavkami vyplývajúcimi $\mathrm{z}$ článku 47 a článku 48 ods. 2 Charty $^{18}$. V uvedenom prípade, po skonštatovaní súladu sekundárneho právneho aktu Únie s Chartou, nebolo možné, aby sa tento akt napokon neuplatnil len preto, že je $\mathrm{v}$ rozpore $\mathrm{s}$ ústavou členského štátu alebo $\mathrm{s}$ výkladom ústavy vykonaným ústavným súdom. Ako sme naznačili vyššie, v celom probléme ide zrejme o viac, než o obavy Únie $\mathrm{z}$ vyššieho štandardu národnej ochrany práv. Za určitých okolností by sa prípad podobný tomu na ústavnom súde Španielska mohol ocitnút' pred ESLP, ktorý by st'ažovatel'om namietané rozhodnutie členského štátu Únie mohol posúdit' aj ako konanie štátu v rozpore s článkom 53 Dohovoru, z dôvodu vykonávania práva Únie a rešpektovania doktríny Melloni. Momentálne, pred pristúpením EÚ k Dohovoru, môže ESL'P zodpovednost' za konštatované porušenie Dohovoru vyvodzovat' len voči členskému štátu, v prípadoch, kedy koná podl'a ustanovení práva Únie. Je dôležité, aby takéto rozhodnutie ESLPP, ktoré konštatuje porušenie práva garantovaného Dohovorom sekundárnym únijným právom, zaväzovalo aj EÚ, pretože iba jej inštitúcie majú právo zmenit' alebo zrušit' sekundárne právo EÚ.

\section{PREDNOSŤ, JEDNOTNOSŤ A ÚČINNOSŤ VZ. ZMYSEL PRISTÚPENIA}

Otázne je aj to, či existuje také riziko ohrozenia prednosti, jednotnosti a účinnosti práva Únie, aby bolo potrebné prijímat' takéto definitívne opatrenie na vylúčenie možnosti poskytovat' vyššiu úroveň ochrany práv na národnej úrovni než je tá, ktorú priznáva Charta pri vykonávaní práva Únie. A tiež to, či strach z narušenia autonómneho postavenia Únie nezatienil všetko ostatné, čo malo byt' zmyslom pristúpenia $\mathrm{k}$ Dohovoru. Zamýšl'ané pristúpenie Únie $\mathrm{k}$ Dohovoru má totiž zabezpečit' účinnejšie a jednotnejšie uplatňovanie základných práv v Európe pričom nesmie byt' dotknutá autonómia právneho poriadku Únie. Uvedená autonómia nie je charakteristická len pre vzt'ah práva Únie $\mathrm{k}$ právu členských štátov, ale musí byt' dodržiavaná aj vo vzt’ahu k tretím krajinám a medzinárodným organizáciám. Na druhej strane, z medzinárodnoprávnej väzby na Dohovor budú pre Úniu nepochybne vyplývat' obmedzenia pri výkone jej existujúcich právomocí. Dohovor ako medzinárodná dohoda uzatvorená Úniou totiž bude mat' po jej pristúpení pre inštitúcie Únie záväzné účinky (článok 216 ods. 2 ZFEÚ). ,,Takéto obmedzenia pri výkone právomoci však vychádzajú z povahy každej právnej úpravy, v ktorej sú zaručené základné práva. Primárnou funkciou základných práv je totiž klást' medze činností štátnych a medzinárodných orgánov $\mathrm{v}$ záujme ochrany subjektov práv. Záväzok pristúpenia $\mathrm{k}$ Dohovoru

17 Rámcové rozhodnutie Rady 2002/584/SVV z 13. júna 2002 o európskom zatykači a postupoch odovzdávania osôb medzi členskými štátmi (Ú. v. EÚ L 190, s. 1; Mim. vyd. 19/006, s. 34), zmenené a doplnené rámcovým rozhodnutím 2009/299/SVV z 26. februára 2009 (Ú. v. EÚ L 81, s. 24).

18 Právo na účinný prostriedok nápravy a na spravodlivý proces a právo na obhajobu. 
obsiahnutý v článku 6 ods. 2 prvej vete ZEÚ by stratil svoj zmysel, ak by Únia nemohla akceptovat' obmedzenia vyplývajúce $\mathrm{z}$ Dohovoru pre výkon jej právomocí. “'19 $\mathrm{S}$ poukazom na citované stanovisko generálnej advokátky, ktorá mimochodom nič také ako tenziu alebo dokonca kolíziu článkov 53 vo svojom stanovisku neuvádza, je na mieste otázka, či Únia nestratila plynutím dlhých štyridsiatich rokov spred očí hlavnú myšlienku pristúpenia a je tiež možné, že si čoraz slabšie uvedomuje nevyhnutné zásahy, ktoré sú predpokladom a dôsledkom pristúpenia. ${ }^{20}$

Pýtame sa tiež, ako možno od pristúpenia očakávat’ zjednotenie uplatňovania základných práv v Európe a zároveň mat' dvojaký meter pre štandard ochrany práv vo veciach, ktoré nepatria do pôsobnosti práva Únie a potom $\mathrm{v}$ tých, $\mathrm{v}$ pôsobnosti práva Únie $\mathrm{v}$ zmysle čl. 51 ods. 1 Charty?

Ak hovoríme o momentálnom naladení Súdneho dvora, nemáme na mysli len stanovisko 2/13. Obdobie, ktoré sa pracovne nazýva post-opinion (po-stanovisku) možno označit' ako obdobie rastúceho centrizmu Charty, v ktorom Súdny dvor interpretuje Chartu bez odkazovania na Dohovor a na judikatúru ESL'P a v ktorom sudcovia v Luxemburgu menej často citujú ESL'P, čo sa javí ako zdôrazňovanie vlastného katalógu základných práv Únie a ich autonómneho výkladu. ${ }^{21} \mathrm{Aj}$ tón Súdneho dvora pôsobí formálnejšie. Dobrým príkladom týchto tvrdení je rozsudok Vel'kej komory vo veci C- 601/15, kde sa konštatuje, že platnost' noriem sekundárneho práva Únie treba preskúmat' len vzhl'adom na základné práva zaručené Chartou ${ }^{22}$. V tomto rozsudku sa Súdny dvor tiež pokúša minimalizovat’ účinok článku 52 ods. 3 Charty tvrdiac, že ciel'om odseku 3 tohto článku je zabezpečit' potrebnú súdržnost' medzi Chartou a Dohovorom „bez toho, aby tým bola narušená autonómia práva Únie a Súdneho dvora Európskej únie““. ${ }^{23}$ Judikatúra ESL’P sa nezdá byt' súčast'ou úvah, ktoré vedú $\mathrm{k}$ výkladu ustanovení Charty, ale Súdny dvor ju používa iba na to, aby podporil závery, ku ktorým už sám dospel. Centrizmus Charty je obzvlášt' viditel'ný v rozsudkoch, v ktorých sa Súdny dvor neodvoláva na judikatúru ESLP, hoci by sa to $\mathrm{v}$ danom prípade hodilo, alebo v konaniach, kde strany výslovne upozorňujú na príslušné rozsudky ESL'P. Alebo ešte zvláštnejšie pôsobí, ked' generálny advokát vo svojom stanovisku uvádza, že daná vec pripomína judikatúru ESL'P, ktorý sa dlhodobo uvedenou problematikou zaoberá, no Súdny dvor vo svojom rozsudku napokon pracuje iba s Chartou. ${ }^{24} \mathrm{Na}$ druhej strane, to čo na prvý pohl'ad vyzerá ako centrizmus Charty, môže byt' len prirodzený následok existencie a záväznosti vlastného katalógu základných práv v Únii, teda zníženie záujmu o Dohovor. Pre úplnost' treba poznamenat', že ESLPP nezrkadlí tento trend Súdneho dvora a neodpovedá na stanovisko 2/13 znížením odkazov na právo EÚ. Naopak, Charta spôsobuje, že právo EÚ je pre ESLP atraktívnejšie, a naviac, ked’že niektoré ustanovenia Charty poskytujú vyššiu úroveň ochrany ako Dohovor, judikatúru ESL’P to môže ešte posilnit'. ${ }^{25}$ Považujeme za dôležité uviest', že tento náčrt signálov, ktoré Súdny dvor vysiela v období po zverejnení

19 Stanovisko Generálnej advokátky J. Kokott zo dňa 13. júna 2014, EU:C:2014:2475, bod 40-41.

20 NERGELIUS, J.: The accession of the EU to the European Convention on Human Rights A critical analysis of the Opinion of the European Court of Justice. [online], [cit. 16/05/2019]. Dostupné na internete: $<$ http://www.sieps.se/en/publications/2015/the-accession-of-the-eu-to-the-european-convention-on-humanrights-a-criticalanalysis-ofthe-opinion-of-the-european-court-of justice-20153/sieps_2015_3>.

21 KORENICA, F.: The EU Accesion to the ECHR. Between Luxembourg's Search for Authonomy and Strasbourg's Credibility on Human Rights Protection. Brusel: Springer, 2015, 63s.

22 Rozsudok Súdneho dvora zo dňa 15. februára 2016, PPU J.N, vec C-601/15, EU:C:2016:84, bod 46; rovnako RozsudokSúdneho dvora zo dňa 28. júla 2016, Ordre des barreauxfrancophones et germanophone a i., vec C-543/14, EU:C:2016:605, bod 23 .

23 Rozsudok Súdneho dvora zo dňa 15. februára 2016, PPU J.N, vec C-601/15, EU:C:2016:84, bod 47.

24 Stanovisko AG Cruz Villalón zo dňa 6. októbra 2015, Thierry Delvigne v Commune de Lesparre Médoc and Préfet de la Girondevec C-650/13, Delvigne, EU:C:2015:363, bod 109.

25 GLAS, R. - KROMMENDIJK, J.: From Opinion 2/13 to Avotiňš: Recent Developments in the Relationship between the Luxembourg and Strasbourg Court. [online], [cit. 20/05/2019]. Dostupné na https://doi.org/10.1093/hrlr/ngw047. 
stanoviska 2/13, do nášho článku vkladáme pre ilustráciu toho, akým smerom sa uberajú nálady Únie v súvislosti s pristúpením.

\section{ZÁVER}

Načrtnutou komparáciou úrovne ochrany práv garantovaných Dohovorom a Chartou možno dospiet' k záveru, že obidva články 53 síce znejú limitujúco, na druhej strane, vel'kú službu im obom robia Súdny dvor a ESLP, ked’ svojou judikatúrou naopak limitujú národnú ústavnú mieru ochrany l'udských práv, a to aj $\mathrm{v}$ tých prípadoch, ktoré štátom vyplývajú $\mathrm{z}$ medzinárodných záväzkov ochrany základných práv. Súdny dvor má okrem toho záujem obmedzit’ pre prípad pristúpenia Únie k Dohovoru aj pôsobenie článku 53 Dohovoru vo vzt’ahu k tým právam, ktoré garantuje Charta, vo veciach, ktoré patria do pôsobnosti práva Únie. Obavy Súdneho dvora plynú z možnej straty autonómie práva Únie, z vyvodzovania zodpovednosti voči Únii po aktivácii mechanizmu spolužalovaného, z prejavov nespokojnosti členských štátov voči diktátu judikatúry Súdneho dvora alebo $\mathrm{z}$ ohrozenia princípov prednosti, jednotnosti a účinnosti práva Únie. Situácia v čase vyjednávaní o pristúpení sa zatial' javí ako budovanie steny z judikatúry sústred'ujúcej sa hlavne na Chartu tak, aby bola neprehliadnutel'ná a nespochybnitel'ná perspektíva naznačená v stanovisku 2/13 a v d’alších rozsudkoch Súdneho dvora, napríklad v rozsudku Melloni, z ktorého sa medzitým stala doktrína neprekonatel'nosti štandardu ochrany základných práv garantovaných Chartou. Ak je toto naozaj vlak, do ktorého Únia nastúpila, máme za to, že ani napriek úspešnému pristúpeniu k Dohovoru, k zefektívneniu ochrany práv jednotlivca v Európe nedôjde.

\section{KLÚČOVÉ SLOVÁ}

pristúpenie, koordinácia úrovne ochrany práv, Dohovor, Charta.

\section{KEY WORDS}

accession, coordination of the level of protection of rights, the Convention, the Charter.

\section{POUŽITÁ LITERATÚRA}

1. BARANÍK, K.: Interakcia medzinárodného, supranacionálneho a ústavného práva pri ochrane l’udských práv v SR. In: Justičná revue, 69, 2017, č. 10, s. $1117-1137$.

2. Charta základných práv Európske únie, Úradný vestník EÚ, dňa 26.10.2012, C 326/391.

3. Council of Europe: European Convention on Human Rights with additional Protocols, Strasbourg, 1950. Dostupné na internete: http://www.echr.coe.int/Documents/Convention_ENG.pdf.

4. GLAS, R. - KROMMENDIJK, J.: From Opinion 2/13 to Avotinš: Recent Developments in the Relationship between the Luxembourg and Strasbourg Court. [online], [cit. 20/05/2019]. Dostupné na https://doi.org/10.1093/hrlr/ngw047.

5. JACQUÉ, J.: What next after Opinion $2 / 13$ of the Court of Justice on the accession of the EU to the ECHR? [online], [cit. 8/05/2019]. Dostupné na internete: $<$ file://C:/Users/MOHI/Downloads/QA0416603ENN.en\%20(1).pdf>.

6. KORENICA, F.: The EU Accesion to the ECHR. Between Luxembourg's Search for Authonomy and Strasbourg's Credibility on Human Rights Protection. Brusel: Springer, 2015, $163 \mathrm{~s}$. 
7. MAZÁK, J.: Prípad Melloni a Ústavný súd Španielska: Praktická ukážka viacúrovňovej ochrany základných práv a slobôd v kontexte prednosti a účinnosti práva Únie. In: Bulletin slovenskej advokácie 6/2014, s 25-31.

8. NERGELIUS, J.: The accession of the EU to the European Convention on Human Rights A critical analysis of the Opinion of the European Court of Justice. [online], [cit. 16/05/2019]. Dostupné na internete: <http://www.sieps.se/en/publications/2015/the-accession-of-the-euto-the-european-convention-on-human-rights-a-critical-analysis-ofthe-opinion-of-theeuropean-court-of-justice-20153/sieps_2015_3>.

9. Rámcové rozhodnutie Rady $2002 / 584 / \mathrm{SVV}$ z 13. júna 2002 o európskom zatykači a postupoch odovzdávania osôb medzi členskými štátmi (Ú. v. EÚ L 190, s. 1; Mim. vyd. 19/006, s. 34), zmenené a doplnené rámcovým rozhodnutím 2009/299/SVV z 26. februára 2009 (Ú. v. EÜ L 81, s. 24).

10. Rozhodnutie Európskeho súdu pre l’udské práva zo dňa 7. februára 2012 vo veci Axel Springer AG v. Nemecko, St’ažnost' č. 39954/08.

11. Rozsudok Súdneho dvora zo dňa 15. februára 2016, PPU J.N, vec C-601/15, EU:C:2016:84, bod 46.

12. Rozsudok Súdneho dvora zo dňa 28. júla 2016, Ordre des barreauxfrancophones et germanophone a i., vec C 543/14, EU:C:2016:605, bod 23.

13. Rozsudok Súdneho dvora zo dňa 15. februára 2016, PPU J.N, vec C-601/15, EU:C:2016:84, bod 47.

14. Rozsudok Súdneho dvora zo dňa 5. októbra 2010, J. McB. proti L.E., vec C-400/10, EU:C:2010:582, bod 53.

15. Rozsudok Súdneho dvora zo dňa 18. decembra 2014, Centre public d'actionsociale d'Ottignies-Louvain-la-Neuve proti Moussovi Abdidovi, vec C-562/13, EU:C:2014:2453, bod 47.

16. Rozsudok Súdneho dvora zo dňa 26. februára 2013, Stefano Melloni proti Ministerio Fiscal, C-399/11, EU:C:2013:107, bod 60.

17. Stanovisko AG Cruz Villalón zo dňa 6. októbra 2015, Thierry Delvigne v Commune de Lesparre Médoc and Préfet de la Girondevec C-650/13, Delvigne, EU:C:2015:363, bod 109.

18. Stanovisko Generálnej advokátky J. Kokott zo dňa 13. júna 2014, EU:C:2014:2475, bod 4041.

19. Stanovisko Súdneho dvora z 18. decembra 2014, 2/13, EU:C:2014:2454, bod 189.

\section{KONTAKTNÉ ÚDAJE AUTORA}

\section{JUDr. Jana Vrabl'ová}

externá doktorandka

Univerzita Pavla Jozefa Šafárika v Košiciach, Právnická fakulta, Ústav medzinárodného práva a európskeho práva

Kováčska 26, P.O.BOX A-45, 04075 Košice, Slovenská republika

Tel: 00421944338221

email: jana.vrablova@student.upjs.sk 